\title{
Estrous Performance of Etawah Crossbred Goats Following Different Estrous Synchronization Methods
}

\author{
Nurcholidah Solihati*, Siti Darodjah Rasad, Kikin Winangun and Toha \\ Department of Animal Production, Faculty of Animal Husbandry, Universitas Padjadjaran, Sumedang, Indonesia \\ *Corresponding author email: nurcholidah@unpad.ac.id
}

\begin{abstract}
The objective of the research was to determine the estrous profile of Etawah Crossbred goats after estrous synchronization with different methods. Eighteen does aged 12-24 month old were divided in three groups to receive estrous synchronization treatments ( $T 1=14$ days intravaginal implant of $60 \mathrm{mg}$ of progesterone (MPA), T2 = two times injection of 5 mg PGF $2 \alpha$ (lutalyse) in 11 days interval, and T3 = 10 days of intravaginal implant of $60 \mathrm{mg}$ of progesterone (MPA) + injection of $5 \mathrm{mg}$ PGF $_{2 \alpha} 48$ hours before removal) with six replications. The parameters consisted of estrous behaviour, changes in size and colour of vulva, and duration of estrus when the number of superficial and keratin cells were dominating in the vaginal mucus cell. Data from estrous behaviour and score of vulvar colour was analyzed using Kurkal Wallis test, while onset of estrus, size of vulva slit and estrous duration was analyzed using ANOVA and Duncan test. The result showed that estrous behaviour and changes in color and size of vulva were not significantly different, but estrous duration was significantly different. Estrous duration in T1 (31.30 hour) and T2 (31.10 hour) was significantly longer than that of T3 (11.36 hour). It is concluded that different methods of estrus synchronization affected estrous quality equally but it affected the estrous duration differently based on vaginal mucus cells. Treatment implant vaginal sponge content progesterone for 14 days and double injection of PGF $2 \alpha$ with 11-day interval given longest estrous duration.
\end{abstract}

Keywords: synchronization, etawah crossbred goat, behaviour, color and size, duration

\begin{abstract}
Abstrak. Tujuan penelitian ini untuk mengetahui profil estrus kambing Peranakan Etawah setelah disinkronisasi estrus dengan beberapa metoda. Delapan belas kambing betina umur 12-24 bulan dibagi menjadi tiga kelompok untuk mendapatkan perlakuan sinkronisasi estrus (T1 = implan intravaginal $60 \mathrm{mg}$ progesteron (MPA) selama 14 hari, T2 = dua kali injeksi 5 mg PGF $2 \alpha$ (lutalyse) selang 11 hari, dan T3 = implan intravaginal 60 mg progesteron (MPA) selama 10 hari+injeksi 5 mg PGF $2 \alpha 48$ jam sebelum pencabutan spon), dengan enam ulangan. Parameter terdiri dari tingkah laku estrus, perubahan ukuran dan warna vulva, dan durasi estrus berdasarkan waktu sel superfisial dan keratin mendominasi sel mucus vagina. Data dari tingkah laku estrus dan skor warna vulva dianalisis dengan Kurkal Wallis, sedangkan onset estrus, ukuran celah vulva dan durasi estrus dianalisis dengan ANOVA dan uji Duncan. Hasil menunjukkan bahwa tingkah laku estrus, perubahan warna dan ukuran vulva tidak berbeda nyata, tetapi durasi estrus menunjukkan perbedaan yang nyata. Durasi estrus yang diperlihatkan oleh T1 (31,30 jam) dan T2 (31,10 jam) nyata lebih panjang dibanding T3 (11,36 jam). Disimpulkan bahwa perbedaan metode sinkronisasi estrus memberikan pengaruh yang sama terhadap kualitas estrus tetapi memberikan pengaruh yang berbeda terhadap durasi estrus berdasarkan sel mukus vagina. Perlakuan implan intravaginal spon yang berisi progesteron selama 14 hari dan dua kali injeksi PGF $2 \alpha$ selang 11 hari menghasilkan durasi estrus paling lama.
\end{abstract}

Kata Kunci: sinkronisasi, kambing peranakan etawah, tingkah laku, warna dan ukuran, durasi

\section{Introduction}

Etawah crossbred goats are dairy animal with high selling value. In order to improve reproductive efficiency, reproductive management is a major concern to be well managed. Of the many factors of reproductive management is the method for detecting estrous for Artificial Insemination (AI). The accuracy of estrous detection and time of $\mathrm{Al}$ is the key to the success of fertilization. In the great population of animal, detecting estrous is not easy to do and, therefore, needs a synchronized method to facilitate the implementation of estrous detection.

Estrous synchronization can be managed by different programs, including single or combined hormones. The method of estrous synchronization is based on two principles: a 
prolonged luteal phase and a shorter luteal phase. In our previous research, we used a vaginal sponge containing progesterone hormone to synchronize in sheep. This method was very simple and economic compared to the implant of controlled internal drug released (CIDR) (Nogueira et al., 2015; Muin et al., 2013; Solihati, 2008) or double injection of prostaglandin $F_{2 \alpha}\left(\right.$ PGF $\left._{2 \alpha}\right)$ (Esteves et al., 2013). Studies on the dose and types of progresteron contained in the sponge for Etawah Crossbred goats have been conducted, so we go on to research about the effectiveness of this method compared to others. This research aims to analyze the profile of estrous in Etawah crossbred goats after synchronization with different methods.

We used three treatments consisted of the implant of vaginal sponge that contained $60 \mathrm{mg}$ of progesterone medroxy progesterone acetate (MPA) for 14 days, double injection of $5 \mathrm{mg}$ $\mathrm{PGF}_{2 \alpha}$ with 11-day interval, and the implant of vaginal sponge containing $60 \mathrm{mg}$ of progesterone MPA for 10 days + injection of 5 mg PGF ${ }_{2 \alpha}$ at 48 hours before the end of implant. The dose was offered based on our previous, unpublished preliminary study.

The differences between these treatments include the effect of hormone, whereas progesterone implant in sponge could inhibit folliculogenesis in 14 days and estrus will come after the sponge was released from the goats. On the other hand, the injection of PGF ${ }_{2 \alpha}$ could degrade the corpus luteum, so the animals experience the proestrus phase and then estrus. In the combined treatments, progesterone inhibits folliculogenesis in follicular phase and $\mathrm{PGF}_{2 \alpha}$ would degrade the corpus luteum. These differences of hormonal mechanism would influence the level of estrogen embodied in the estrous behaviour, and the changes of vulva and duration of estrus.

The objective of the research was to determine the estrous profile of Etawah
Crossbred goats after estrous synchronization with different methods.

\section{Materials and Methods}

This research used eighteen Etawah crossbred does aged 12-24 month and weighed $25-30 \mathrm{~kg}$. The does were reared in individual cages, fed with $300 \mathrm{~g}$ of concentrate/head/day and offered with grass and water ad libitum. The estrous synchronization used vaginal sponge implant methods contained progesterone and $\mathrm{PGF}_{2 \alpha}$ injection. Eighteen does were allotted into three groups of estrous synchronization treatment, and each group had six does as replication. The treatments consisted of:

1) T1 (implant of vaginal sponge containing 60 $\mathrm{mg}$ of progesterone MPA for 14 days),

2) $\mathrm{T} 2$ (double injection of $5 \mathrm{mg} \mathrm{PGF}_{2 \alpha}$ with an interval of 11 days)

3) T3 (implant of vaginal sponge containing 60 $\mathrm{mg}$ of progesterone MPA for 10 days + injection of $5 \mathrm{mg} \mathrm{PGF} 2 \alpha$ at 48 hours before the end of implant).

The estrous was detected three times per day, in the morning (07.00 AM), afternoon (03.00 PM) and evening (08.00 PM). The parameters that were observed for seven days after the end of the treatment consisted of the estrous onset, estrous occurrence, estrous behaviour, colour of vulva, length and width of the vulva slit, and the duration of estrous. According to Ismail (2019) estrous behavior is evaluated in a four-scale score. Score zero (0) is no estrus; score one (1) is the silent heat; score two (2) is restless, with an intense bleating, selfrubbing against the wall, wagging tail while looking at the male, and decreased appetite; and score three (3) is the standing heat, restlessness, and increased intensity of bleating, rubbing against the wall, wagging tail while looking at the male, and decreased appetite). The colour of vulva was rated using a Salmofan indicator with a range from 20 to 34 (DSM, 
2007). The length and width of the vulva slit were measured by calipers $(\mathrm{cm})$. The estrous duration was evaluated based on the existence of superficial and keratin cells. Vaginal mucus cell cytology was used to determine the length of the estrous phase that appeared daily for seven days after the treatment. The results were the duration of superficial cell dominance that appeared to show the estrous period.

Data from estrous behaviour and score of vulva colour was analyzed by Kurkal Wallis, while onset of estrous, size of vulva slit and estrous duration was analyzed by ANOVA and Duncan test.

\section{Results and Discussion}

\section{Onset of Estrous}

The result showed that the onset of estrus appeared from T2 (69.03 \pm 14.19 hours), followed by T3 $(76.93 \pm 9.90$ hours) and T1 (85.30 \pm 26.01 hours). The result of ANOVA showed no significant difference in the onset of estrus after treatment $\mathrm{T} 1, \mathrm{~T} 2$ and $\mathrm{T} 3$.

This result showed that intravaginal implant of sponge for 14 days resulted in the same onset of estrous in both $\mathrm{PGF}_{2 \alpha}$ treatment and combined sponge and $\mathrm{PGF}_{2 \alpha}$. This result confirms previous study that CIDR treatment for 14 days with 400 IU of pregnant mare serum gonadotropin (PMSG) and $0.05 \mathrm{mg}$ of cloprostenol given at CIDR withdrawal tend to shorten the time of oestrus responses and result in a more compact onset of oestrus (Muin et al., 2013). Other researcher explained that when the CIDR was in place, the progesterone concentration remained high due to exogenous progesterone from the CIDR, but at CIDR withdrawal time, the progesterone concentration rapidly declined which mimics the normal condition and subsequently with high oestradiol and low progesterone led the animal to exhibit oestrus behaviour (Sobayil, 2010). Also, goats treated with vaginal CIDRs or sponges accompanied by the injection of equine chorionic gonadotropin (eCG) showed a higher percentage of estrus expression and fertility during the non - breeding season of Ardy goats (Sobayil, 2010). Furthermore, it was reported that the source of progestin did not influence the efficiency of estrus synchronization rate in CIDR vs sponges ( $80 \%$ vs. $73 \%$ ) (Sobayil, 2010). CIDRs did not cause bad smell in comparison with sponges. The use of CIDR, sponge, or implant treatments alone or with eCG is equally efficient in synchronizing estrus in goats (Hashemi and Safdarian, 2017).

This result was in accordance a study by Omontese et al., (2012) that the 14 - day fluorogestone acetate sponge treatment alone could synchronize estrus in Sahel goats but the additional administration of eCG increases estrus response, shortens time to onset of estrus, lengthens the duration of estrus and tightens estrus synchrony. The onset of estrous from $\mathrm{PGF}_{2 \alpha}$ treatment of this research was longer than 69.03 hours, compared to a previous study that the interval of estrus after the second dose of $\mathrm{PGF}_{2 \alpha}$ was $48 \mathrm{~h}$ (Esteves et al., 2013). This might be the result of the administration route.

The result of the present study showed that the intravaginal sponge with progesterone is suitable as the estrous synchronization method. This result was in accordance with other study that the intravaginal sponge treatment is effective in achieving synchronous estrus in a large group of animals, thereby facilitating the farmers to go for natural mating or to undertake modern assisted reproductive technologies (Chakraborty et al., 2015). Following cessation of the progestagen treatment, ewes will come into heat and ovulate. The time interval for the onset of estrus varies with the age of the ewe, time of year, and the type of progestagen treatment and its duration. Intramuscular injection of follicle-stimulating hormone (FSH) in the form of eCG at the end of the progestagen treatment supports follicular growth and ovulation rate and causes better synchronizatio $\mathrm{n}$ of estrus and ovulation (Gootwine, 2011). 
Table 1. The Occurrence of Estrous

\begin{tabular}{|c|c|c|c|c|c|c|c|c|c|}
\hline \multirow{2}{*}{$\mathrm{T}$} & \multirow{2}{*}{$\mathrm{N}$} & \multicolumn{7}{|c|}{ Day- } & \multirow{2}{*}{$\begin{array}{c}\text { Total } \\
\text { (head) }\end{array}$} \\
\hline & & 1 & 2 & 3 & 4 & 5 & 6 & 7 & \\
\hline \multicolumn{10}{|c|}{. } \\
\hline $\mathrm{T} 1$ & 6 & 0 & 0 & 2 & 2 & 1 & 1 & 0 & 6 \\
\hline T2 & 6 & 0 & 0 & 3 & 3 & 0 & 0 & 0 & 6 \\
\hline T3 & 6 & 0 & 0 & 1 & 4 & 0 & 0 & 0 & 5 \\
\hline T1 & \multicolumn{9}{|c|}{$=60 \mathrm{mg}$ implant intravaginal progesterone (MPA) for 14 days } \\
\hline $\mathrm{T} 2$ & \multicolumn{9}{|c|}{$=$ doble injections of $5 \mathrm{mg}$ PGF2 $\alpha$ (lutalyse) with 11-day interval } \\
\hline T3 & \multicolumn{9}{|c|}{$\begin{array}{l}=60 \mathrm{mg} \text { implant intravaginal progesterone (MPA) for } 10 \text { days+ injection of } 5 \mathrm{mg} \text { PGF } 2 \alpha \text { at } 48 \text { hour before the end } \\
\text { of treatment (day 8). }\end{array}$} \\
\hline
\end{tabular}

\section{The Occurrence of Estrus}

The estrus occurred between day 3 and day 5 after the end of treatment. The most occurrence of estrus was on day-4. The result of Cochran test showed that estrous synchronization method did not significantly affect the occurrence of estrus.

The use of intravaginal sponges impregnated with $45 \mathrm{mg}$ cronolone and $0.5 \mathrm{ml} \mathrm{PGF}_{2 \alpha}$ combined is convenient for estrus synchronization in Turkish Saanen goats in Turkey during the breeding season (Ince and Köker, 2011). The result of this research was higher than $76 \%$ does in estrous after the first prostaglandin administration reported by Esteves et al. (2013). However, a similar percentage was obtained after the second dose (79\%).

\section{Estrous Behaviour}

Estrous behaviour appeared on day 3 was evaluated by scoring. Table 2 shows that the modus (the prevalent number of scoring) of all treatments is three (3). The result of Kruskal Wallis test showed no significant difference in estrous behaviour after the treatment of estrous synchronization methods.

This result was in line with another study that the reproductive performance of the Raieni goats was not significantly affected by the method of estrous synchronization, but cloprostenol injection was found to be more convenient and economical under the conditions of this experiment during the breeding season (Kor et al., 2011). Nevertheless, an ovsynch with sponge treatment may be a useful alternative to the traditional vaginal sponge treatment as well as ovsynch treatment to augment fertility in Tellicherry goats (Senthilkumar et al., 2016). Estrus synchronization using intravaginal CIDR implant for 7 days combined with $\mathrm{PGF}_{2 \alpha}$ on day 6 was effective for the estrus synchronization of dairy cows (Solihati, 2008).

The end of estrous synchronization resulted in the decrease of progesterone then stimulated the follicle stimulating hormon (FSH) secretion in high concentration. Thus, FSH leads to the development of granulosa cells and produces estrogen (Wumbu, 2003). The high concentration of estrogen would trigger the goats to exhibit the estrous behaviour.

Table 2. Score of Estrous Behaviour

\begin{tabular}{|c|c|c|c|}
\hline \multirow{2}{*}{ Replication } & \multicolumn{3}{|c|}{ Score of Estrous Behaviour } \\
\hline & $\mathrm{T} 1$ & $\mathrm{~T} 2$ & T3 \\
\hline 1 & 2 & 3 & 0 \\
\hline 2 & 2 & 3 & 3 \\
\hline 3 & 3 & 3 & 3 \\
\hline 4 & 3 & 3 & 2 \\
\hline 5 & 3 & 3 & 3 \\
\hline 6 & 3 & 3 & 3 \\
\hline Modus & 3 & 3 & 3 \\
\hline \multicolumn{4}{|c|}{$\begin{aligned} \mathrm{T} 2= & \text { doble injections of } 5 \mathrm{mg} \mathrm{PGF}_{2 \alpha} \text { (lutalyse) with 11-day } \\
& \text { interval }\end{aligned}$} \\
\hline \multicolumn{4}{|c|}{$\begin{aligned} \mathrm{T} 3= & 60 \mathrm{mg} \text { implan intravaginal progesteron (MPA) for } 10 \\
& \text { days + injection of } 5 \mathrm{mg} \mathrm{PGF} \text { Pa }^{\alpha} \text { at } 48 \text { hour before the } \\
& \text { end of treatment (day 8). }\end{aligned}$} \\
\hline
\end{tabular}

\section{The Changes of Vulvar Colour}

The traits shown by estrous goats are the change of vulvar colour from initially pale to reddish. The results of the vulvar colour 
assessment for seven days of observation in treated goats using the Salmofan colour indicator are presented in Table 3. The result of Kruskal Wallis test showed that there was no significant difference of colour of vulva after treatment with different synchronization methods. All treated animals showed red colour at their vulva.

The result of Kruskal Wallis test showed that there was no significant difference of colour of vulva after treatment of different synchronization methods. All of the animals treated showed red colour at their vulva. The colour changes was influenced by estrogen that increased at estrus (Widiyono et al., 2011).

Frandson et al. (2003) explained that after progesterone treatment ended and $\mathrm{PGF}_{2 \alpha}$ was injected, FSH increased thus folliculogenesis occured and granulosa cells in follicle developed to produce estrogen untill follicle de Graaf where estrogen in maximal level. This will stimulate the thickening of the vaginal wall, increased vascularization causing the outer genitals to change colour from pale to reddish accompanied by swelling and more mucus secretion.

\section{Changes of Vulvar Size}

The goats in estrus will experience the vulvar colour to a reddish colour accompanied by an enlarged size. The swelling of the vulva is seen from the widening of the vulvar lips and the increased length of the vulval cleft when the goats were in the estrous phase. The measurements of the width and length of the vulval cleft for seven days of observation after the termination of treatment were presented in Table 4 and Table 5.

The result of ANOVA from data of $3^{\text {rd }}$ day measurement showed that there was no significant difference in the width and length of the vulva lip of goat in estrus after treated with different methods of estrus synchronization. This showed that all three treatments has the same effect on the widening of vulvar lips and the length of the vulvar cleft that reached the maximum size when the goat is in estrus phase, i.e., on the $3^{\text {rd }}$ day.

The increase in length and width of the vulva from day 1 to 3 is indicative of an increase in estrogen that causes vascularization of the vulvar wall periodically. The increased estrogen is due to FSH released after the progesterone declines because of the discharge of synchronization method that actively stimulates folliculogenesis. The granulosa cells that grow with follicle will begin to produce estrogen that reaches its peak when the follicle matures. The vulvar swelling of all treated goats is considered normal because it corresponds to the longeracting size of the longitudinal bligon estrus vulva $(3.06 \mathrm{~cm})$ than during the anestrus condition $(2.58 \mathrm{~cm}$ ) (Wumbu, 2003) and the size of the Dwarf goat vulva gap African estrus (1.88 $\mathrm{cm}$ ) is longer than in anestrus conditions (1.85 $\mathrm{cm}$ ) (Leigh et al., 2010).

Table 3. Modus of Vulvar Lips Score

\begin{tabular}{|c|c|c|c|c|c|c|c|c|c|c|c|}
\hline \multirow{2}{*}{\multicolumn{2}{|c|}{ Treatment }} & \multirow{2}{*}{$\mathrm{N}$} & \multicolumn{7}{|c|}{ Day of Observation } & \multirow{2}{*}{ Min } & \multirow{2}{*}{ Max } \\
\hline & & & 1 & 2 & 3 & 4 & 5 & 6 & 7 & & \\
\hline & 1 & 6 & 22 & 22 & 25 & 23 & 22 & 21 & 20 & 20 & 25 \\
\hline & & 6 & 22 & 22 & 23 & 22 & 22 & 22 & 22 & 22 & 23 \\
\hline & 3 & 6 & 22 & 22 & 23 & 23 & 21 & 21 & 21 & 21 & 23 \\
\hline \multicolumn{12}{|c|}{$=$ Treatment } \\
\hline$N$ & \multicolumn{11}{|c|}{$=$ Number of does } \\
\hline Min & \multicolumn{11}{|c|}{$=$ Minimum value } \\
\hline Max & \multicolumn{11}{|c|}{ = Maximum value } \\
\hline
\end{tabular}


Table 4. Average of Vulvar Lips Width

\begin{tabular}{|c|c|c|c|c|c|c|c|c|c|c|}
\hline \multirow{2}{*}{ Treatments } & \multirow{2}{*}{$\mathrm{N}$} & \multicolumn{7}{|c|}{ Days of Observation } & \multirow{2}{*}{ Min } & \multirow{2}{*}{ Max } \\
\hline & & 1 & 2 & 3 & 4 & 5 & 6 & 7 & & \\
\hline & & \multicolumn{8}{|c|}{------------------------------------------------ cm --------------------------------------------1 } & \\
\hline T1 & 6 & 1.41 & 1.54 & 1.60 & 1.49 & 1.37 & 1.43 & 1.28 & 1.28 & 1.60 \\
\hline $\mathrm{T} 2$ & 6 & 1.34 & 1.35 & 1.53 & 1.47 & 1.51 & 1.39 & 1.33 & 1.33 & 1.53 \\
\hline T3 & 6 & 1.34 & 1.25 & 1.37 & 1.29 & 1.31 & 1.30 & 1.24 & 1.24 & 1.37 \\
\hline
\end{tabular}

Table 5. Average of Vulvar Length

\begin{tabular}{|c|c|c|c|c|c|c|c|c|c|c|}
\hline \multirow{2}{*}{$\begin{array}{c}\text { Treatment } \\
\mathrm{s} \\
\end{array}$} & \multirow{2}{*}{$\mathrm{N}-$} & \multicolumn{7}{|c|}{ Days of Observation } & \multirow{2}{*}{ Min } & \multirow{2}{*}{ Max } \\
\hline & & 1 & 2 & 3 & 4 & 5 & 6 & 7 & & \\
\hline & & & ------ & $-----\cdot-$ & $-----\cdot-$ & $-\mathrm{cm}-$ & ----- & ------- & ------- & -- \\
\hline $\mathrm{T} 1$ & 6 & 2.33 & 2.70 & 2.81 & 2.75 & 2.66 & 2.51 & 2.36 & 2.33 & 2.81 \\
\hline $\mathrm{T} 2$ & 6 & 2.32 & 2.50 & 2.73 & 2.55 & 2.45 & 2.49 & 2.34 & 2.32 & 2.73 \\
\hline T3 & 6 & 2.64 & 2.91 & 3.04 & 2.99 & 2.81 & 2.74 & 2.65 & 2.64 & 3.04 \\
\hline
\end{tabular}

\section{Estrous Duration}

The dominance of vaginal mucus cells showed the estrous cyclical phase of the does. The changes of vaginal mucus cytology were evaluated for seven days (D1 to D7) in the Etawah crossbred does treated with different methods of estrous synchronization (Figure 1, 2 and 3). In this study, it was believed that on day 3 of observation the does experienced the estrus phase. In addition to the estrous behaviour and the features of the red, swollen, and slimy vulva, the vaginal mucus cytology also indicated that the dominating cells moved from intermediate cells to superficial cells on $\mathrm{T} 2$ (Figure 2) and T3 (Figure 3) and keratin cells on T1 (Figure 1).

Johnson (2006) reported that estrus vaginal swabs will show the dominance of superficial cells, but keratin cells can be used as a reference that the livestock is in the estrous phase because keratin cells are superficial cells in which keratinization is resulted from high estrogen hormone in the body of the livestock. Mayor et al. (2005) reported that vaginal mucus cells can be distinguished into parabasal, intermediates, superficial, and keratin seen from the nucleus of the cell and its cytoplasm.

The dominance of superficial and keratin cells indicates that the livestock is in the estrus phase so that by looking at its dominance over time, the length of estrus can be determined by calculating the duration of the occurrence of these two cells. The duration of estrus based on vaginal mucus cells of Etawah crossbred goats treated with different estrous synchronization methods is presented in Table 6 .

The results of ANOVA showed that duration of estrus was significantly $(p<0.05)$ affected by the treatment of estrus synchronization methods. Result of Duncan multiple range test, showed that the duration of estrus caused by goats treated with $\mathrm{T} 1$ and $\mathrm{T} 2$ longer than $\mathrm{T} 3$ while between $\mathrm{T} 1$ and $\mathrm{T} 2$ not significant.

Goats normally experience estrus for 24-36 hours (Gimenez and Rodning, 2007). Estrus duration of goats treated with $\mathrm{T} 1$ and $\mathrm{T} 2$ was within the normal range, namely 31.3 hours and 31.1 hours, respectively. It was reported that estrogen levels in the body affect the estrus duration, where high estrogen levels will lead to longer estrus (Tagama, 1995). Treatment of progesterone in vaginal sponge implanted for 14 days and treatment of injection double $\mathrm{PGF}_{2 \alpha}$ interval of 11 days can drastically reduce the progesterone level. Therefore, it optimizes the release of FSH and estrogen secretion to render normal estrus duration on goats. 


\section{Treatment 1}

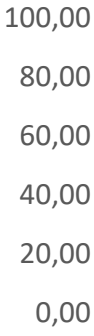

80,00
60,00
40,00
20,00
0,00

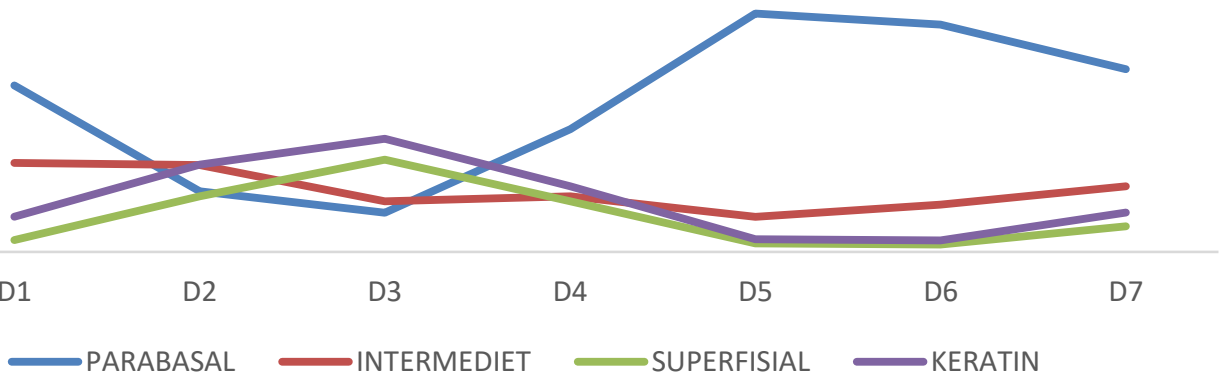

Figure 1. Domination of mucus cell of does treated vaginal implant of sponge content progesteron for 14 days. D1: day 1; D2: day 2: D3: day; D4: day 4; D5: day 5; D6: day 6; D7: day 7.

\section{Treatment 2}

$$
\begin{array}{r}
100,00 \\
80,00 \\
60,00 \\
40,00 \\
20,00 \\
0,00
\end{array}
$$

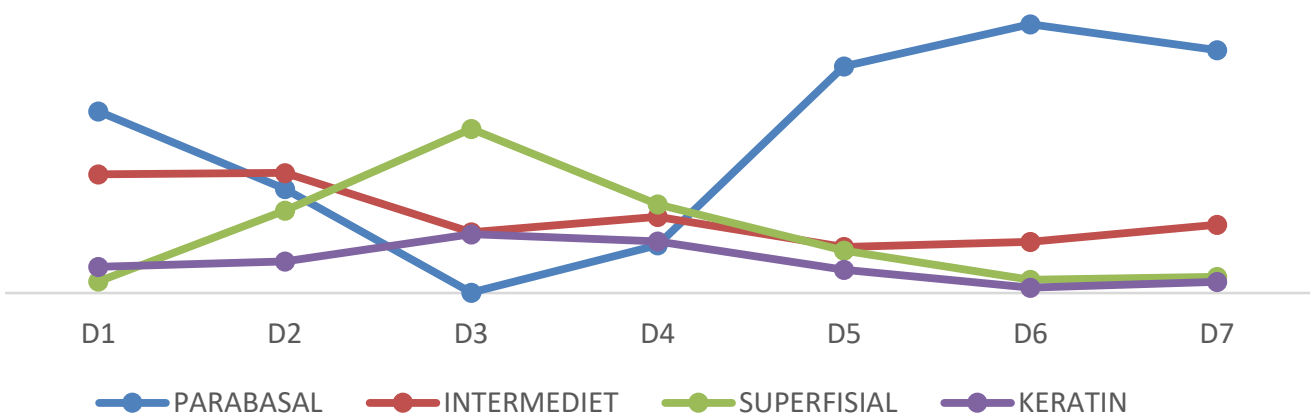

Figure 2. Domination of mucus cell of does treated by double injections of PGF for 11 days. D1: day 1; D2: day 2: D3: day; D4: day 4; D5: day 5; D6: day 6; D7: day 7.

\section{Treatment 3}

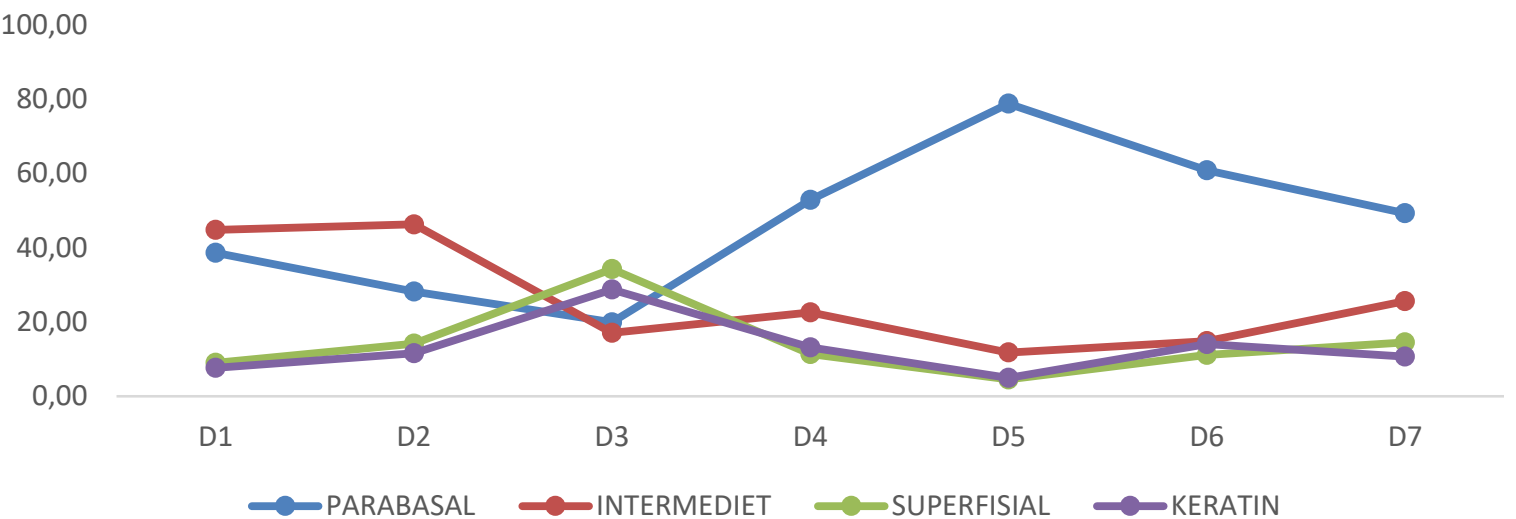

Figure 3. Domination of mucus cell of does treated combination of vaginal sponge implant for 10 days with injection of $\mathrm{PGF}_{2 \alpha} 48$ hours before end of treatment. D1: day 1; D2: day 2: D3: day; D4: day 4; D5: day 5; D6: day 6; D7: day 7. 
Table 6. Estrous Duration

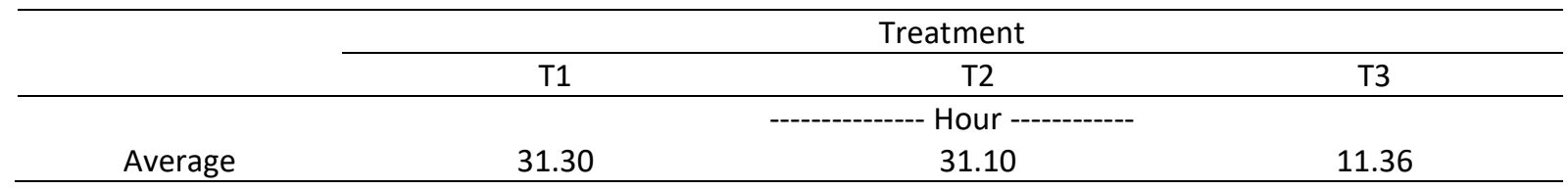

Result of T3, estrus duration shorter than the normal range ( $\mathrm{T} 3=11.36$ hours) and faster than T1 dan T2. Compared to the implant of intravaginal progesterone or double injection, the intravaginal implant of progesterone with an injection of $\mathrm{PGF}_{2 \alpha} 48$ hours before the end of treatment would trigger more follicle; thus increasing the estrogen concentration in the blood (Fernandez-Moro et al., 2008). Based on this research, it was predicted that a combination of progesterone intravaginal implant and injection of $\mathrm{PGF}_{2 \alpha}$ effectively decreased progesterone levels. Therefore, FSH released from anterior hypophysis capable of increased folliculogenesis in the ovarium. The increase of estrogen level is linear to the follicle. Estrogen then gave positive feedback to the hypothalamus and hypophysis to release $\mathrm{LH}$ faster, so the increasing luteinizing hormone (LH) came faster, and thus ovulation and luteinization occurred. This caused estrous duration to last faster.

The duration of estrus in this research was shorter than the one reported by Esteves et al. (2013) and the estrus duration was also different for the first (35.4h) or second (26.8h) estrus. The interval between estrus after the first dose (75.8 h) was significantly longer than after the second dose of $\mathrm{PGF}_{2 \alpha}(47.7 \mathrm{~h})$. Also, Esteves et al. (20013) was reported that a greater synchronization was achieved after the second dose of $\mathrm{PGF}_{2 \alpha}$. It is probably the most desired feature when working with Artificial Insemination in commercial dairy goat systems. Another element to support this assumption is that functional corpus luteum was present in all does at the moment of the second $\mathrm{PGF}_{2 \alpha}$ dose. The presence of an active corpus luteum at the time of the $\mathrm{PGF}_{2 \alpha}$ administration is the key point to determine the success of estrus.

\section{Conclusions}

Etawah Crossbred goats treated by different estrous synchronization methods showed the same estrous quality but different estrous duration. Treatment implant vaginal sponge content progesterone for 14 days and treatment of double injection of $\mathrm{PGF}_{2 \alpha}$ with 11day interval given the longest estrous duration.

\section{Acknowledgement}

This research was supported by Academic Leadership Grand (ALG) Universitas Padjadjaran.

\section{References}

Chakraborty, A, A Bora, and S Sarmah. 2015. Duration of estrus in Assam local goats and its crossbreds following IVS treatment. IOSR J of Agriculture and Veterinary Sci, 8(4): 01-02.

DSM. 2007. The DSM SalmoFan ${ }^{T M}$. [online] DSM in Animal Nutrition \& Health. https://www.dsm.com/markets/anh/en_US/prod ucts/products-

solutions/products_solutions_tools/Products_sol utions_tools_salmon.html (accessed Januari 28, 2017, 05.26 PM).

Esteves, LV, FZ Brandão, RC Cruz, JMG Souza, E Oba, O Facó, and JF Fonseca. 2013. Reproductive parameters of dairy goats submitted to estrus synchronization with prostaglandin $\mathrm{F} 2 \alpha$ associated or not to hCG at estrous onset. Arq. Bras. Med. Vet. Zootec. 65(6): 1585-1592.

Fernandez-Moro, D, A Veiga-Lopez, C Ariznavarreta, J. A. F. Tresguerres, T. Encinas and A. GonzalezBulnes. 2008. Preovulatory Follicle Development in Goats Following Oestrous Synchronization with Progestagens or Prostaglandins. Reprod. Dom. Anim. 43: 9-14.

Frandson, RD, WL Wilke, and AD Fails. 2003. Anatomy and Physiology of Farm Animal. Edisi ke-7. Lippincott Williams \& Wilkins: Philadelphia.

Gimenez, D and S Rodning. 2007. Reproductive Management of Sheep and Goats. Alabama Cooperative Extension System: Alabama.

Gootwine, E. 2011. Husbandry of Dairy Animals I Sheep: Reproductive Management. Encyclopedia of Dairy Sciences : 887-892. 
Hashemi M and M Safdarian. 2017. Efficiency of different methods of estrus synchronization followed by fixed time artificial insemination in Persian downy does. Anim. Reprod. 14(2): 413417.

Ince, D and A Köker. 2011. The effect of estrus synchronization on the reproductive characteristics of Turkish Saanen goats and growth characteristics of kids under extensive conditions. African J. of Agricultural Research. 6 (26): 5715-5719.

Ismail, M. 2009. Onset dan Intensitas Estrus Kambing pada Umur yang Berbeda. J. Agroland 16(2): 180186.

Johnson, C. 2006. Reproductive Disorders in: Laboratory Diagnostics in Small Animal Practice. Urban \& Fischer Verlag: Munchen.

Kor, NM, N Ziaei and EE Pour. 2011. Comparison of Reproductive Performance in Raieni Goats Following Different Estrous Synchronization Methods and Subsequent ECG Treatment During the Natural Breeding Season. Global Veterinaria. 7(6): 618-624, ISSN 1992-6197.

Leigh, OO, AK Raheem, and JAO Olugbuyiro. 2010. Improving the Reproductive Efficiency of the Goat: Vaginal Cytology and Vulvar Biometry as Predictors of Synchronized Estrus/Breeding Time in West African Dwarf Goat. Int. J. Morphol. 28(3): 923-928.

Mayor, P, H Galvez, DA Guimaraes, GF Lopez, and M Lopez. 2005. Serum Estradiol 1-17a, Vaginal Cytology and Vulval Appearance as Predictors of Estrus Cyclicity in the Female Collared Peccary (Tayassu tajacu) from The Eastern Amazon Region. Anim. Reprod. Sci. 97: 165-174.

Muin, HBA, B Hasbudie, MS Suraya, JM Panandam, H Yaakub, J Theivanai, and HNQ Nizamuddin. 2013. Effects of Two CIDR - based Oestrus Synchronization Protocols on Oestrus Response in Boer Goats. Malaysian J. Anim. Sci. 16 (2): 2935.
Nogueira, DM, ESL Junior, RM de Peixoto, M Christilis, SR Martins, and APO do Monte. 2011. Using the same CIDR up to three times for estrus synchronization and artificial insemination in dairy goats. Acta Scientiarum Animal Sciences. Vol. 33 (3), p. 321-325.

Omontese, BO, PI Rekwot, HJ Makun, IU Ate, and J S. Rwuaan. 2012. Induction of estrous in Sahel goays using Fluorogestone Acetate (FGA) sponges and Equine Chorionic Gonadotrophin (ECG). Sokoto J. of Veterinary Sci. 10(2): 21-25

Senthilkumar, K, M Selvaraju, RE Napolean, KA Doraisamy, and B Mohan. 2016. Pattern of Oestrus and Fertility Rate Following Synchronization of Ovulation in Tellicherry Goats. Inter J. of Science, Environment and Technology. 5(5): 3289-3296

Sobayil, KA. 2010. Effectiveness of Different Protocols for Inducing Estrus of Ardy Goats During the Non - Breeding Season. J. of Animal and Poultry Production. 1(2): 35-44

Solihati, N. 2008. Penggunaan Progesteron Intravaginal dan Kombinasinya dengan PGF $2 \alpha$ serta Estrogen dalam Upaya Menimbulkan Estrus dan Kebuntingan pada Sapi Anestrus. Bionatura 10(3). 258-272.

Tagama, TR. 1995. Pengaruh Hormon Estrogen, Progesteron dan Prostaglandin F2 $\alpha$ terhadap Aktivitas Berahi Sapi PO Dara. Fakultas Peternakan Universitas Jendral Sudirman, Purwokerto

Wumbu, MI. 2003. Pengaruh Pemberian Implan Progesteron dan Berbagai Dosis Estradiol Benzoat terhadap Estrus dan Kebuntingan pada Domba Ekor Gemuk. Tesis. Program Pascasarjana Fakultas Peternakan Universitas Padjadjaran: Sumedang.

Widiyono, I, PP Putro, Sarmin, P Astuti, and CM Airin. 2011. Kadar Estradiol dan Progesteron Serum, Tampilan Vulva dan Sitologi Apus Vagina Kambing Bligon selama Siklus Birahi. J. Veteriner. 12: 263268. 